\title{
Preservice Teachers' Awareness Levels Regarding the Signs of Physical Abuse in Children ${ }^{1}$
}

\author{
Münevver CAN-YAŞAR** \\ Gözde İNAL KIZILTEPE*** \\ Adalet KANDIR****
}

Received: 03 December 2013

Accepted: 21 February 2014

\begin{abstract}
In this study, which aimed to investigate the pre-service teachers' awareness levels regarding the signs of physical abuse in children, the sample included 173 subjects from the department of Early Childhood Education, 241 from Elementary Education, 221 from Social Studies Teaching and 129 subjects from the department of Turkish Teaching for a total of 764 pre-service teachers at the Faculty of Education. To collect data, a general information form including demographic characteristics of pre-service teachers and "Physical Abuse Signs Rating Scale" developed by Erol (2007) were used. According to the findings, the difference between Physical Abuse Signs Rating Scale's states, behavioral characteristics and parent behaviors subtest scores according to pre-service teachers' gender, field of study and years of study was not statistically significant whereas the difference between the state and behavioral characteristic scores according to pre-service teachers' educational status regarding child neglect and abuse was found out to be significant.
\end{abstract}

Keywords: child neglect and abuse, physical abuse, pre-service teachers

\section{Extended Abstract}

Purpose and Significance: Physical abuse is the physical damage and deterioration of the integrity of children's body by the people who are responsible for caring for them (Polat, 2007; Yolcu, 2009; Wood \& Ludwig, 2010). Physical abuse is a problem emerging primarily within the family environment; however, in the process it also manifests itself in other environments responsible for the care of children. As the children spend most of their time at school, apart from the time spent at home, school setting is important in that it provides opportunity for the teachers to identify child abuse and prevent it (Baginsky, 2003; Crosson-Tower, 2003; Erol, 2007; Tugay, 2008; Yolcu, 2009; Pala, 2011). It is crucial for the teachers, who have a subsidiary role in the lives of children, to develop awareness regarding abuse phenomena in the sense of protecting children (Goldman, 2005; Walsh, Bridgstock, Farrell \& Schweitzer, 2005). On the other hand, teachers should be pre-service trained to qualify the needs to deal with child neglect and abuse in order to learn preventive issues and develop their professional skills and knowledge. From this point of view, the study aimed to investigate the pre-service teachers' awareness levels regarding the signs of physical abuse in children.

\footnotetext{
* This article was presented at the International Conference on Education and Childhood Education Research, 27-2829 Nisan 2012, Zirve University, Gaziantep, Turkey.

**Assoc. Prof. Dr, Afyon Kocatepe University, Education Faculty, Afyonkarahisar, Turkey, munevver2002@yahoo.com

***Corresponding Author: Assist. Prof. Dr, Adnan Menderes University, Education Faculty, Aydın, Turkey, gozde.kiziltepe@adu.edu.tr

**** Prof. Dr., Gazi University, Education Faculty, Ankara, Turkey, akandir@gmail.com
} 
Methods: This study, which is descriptive and follows the principles of a survey design, encompasses a population including 904 pre-service teachers who were either in their first or fourth years at Afyon Kocatepe University, Faculty of Education. Since the population size is not considerably large, the researchers decided not to do some sampling; thus, the population is also assumed to be the sample of the study because of its convenience. 140 pre-service teachers were left out since they were not willing to participate. In the end, the sample included 173 subjects from the department of Early Childhood Education, 241 from Elementary Education, 221 from Social Studies Teaching and 129 subjects from the department of Turkish Teaching for a total of 764 pre-service teachers at the Faculty of Education. Of the pre-service teachers participated in the study, $60.05 \%$ was female and $34.95 \%$ were male while $50.13 \%$ were between 17 and 20, 47.91\% was between 21 and 25 and 1.96\% was between 26 and 30 years old. Also, $78.14 \%$ of the participants declared that they didn't have any training with reference to child neglect and abuse whereas the rest received some training.

To collect data, a general information form, which was developed by the authors, including demographic characteristics such as the participants' gender, status of training, source of knowledge, awareness of reporting, Child Protection Act and readiness for identifying physical abuse signs and "Physical Abuse Signs Rating Scale" developed by Erol (2007) were used. In the first section of Physical Abuse Signs Rating Scale consisting of two sections, there were a total number of 19 items assessing the status regarding the physical abuse signs (10 items), behavioral characteristics (4 items) and parental behaviors (5 items) whereby a sum of 19 items assessing the same issues were in the second section. In the first section, the items were responded with two points - "yes" or "no" while the items in the second section can be responded as "often", "sometimes" or "never" in three points. The reliability coefficient of the scale was found out as .95 (Erol, 2007). In this study, only the first section was used.

In the analysis of the data collected via General Information Form, descriptive statistics such as percentages and frequency tables were used. Kolmogorov-Smirnoff (K-S) Test were used to identify whether the scores of Physical Abuse Signs Rating Scale showed normal distribution or not. As the distribution did not have the characteristics of a normal distribution, Mann Whitney U test was used for investigating the differences between groups and Kruskal Wallis $\mathrm{H}$ Test was used for more than two groups. 0.05 was set at the significant level while comparing the groups.

Results: According to the results, of the preservice teachers $95.55 \%$ stated that they had the responsibility to report child neglect and abuse according to the laws, $89.92 \%$ according to the Ministry of National Education Regulations and 97.77\% according to ethical manners. Moreover, $67.41 \%$ of the participants stated that they should report to the Police Department and 18.02\% for Social Services. Furthermore, it was found out that $85.73 \%$ had no knowledge of the Child Protection Act and 39.01\% was not sure that they had the certain skills to identify the signs of physical abuse. According to the findings, the difference between Physical Abuse Signs Rating Scale’s states, behavioral 
characteristics and parent behaviors subtest scores according to preservice teachers' gender, field of study and years of study was not statistically significant whereas the difference between the state and behavioral characteristic scores according to preservice teachers' educational status regarding child neglect and abuse was found out to be significant $(\mathrm{p}<.05)$. On the other hand the difference was not significant according to the scores related to parental behaviors.

Discussion and Conclusions: Similar findings were reported in the literature (Kenny, 2004; Tugay, 2008; Pala, 2011) in that 39.01\% of the pre-service teachers stated that they were not sure of their knowledge in identifying physical abuse on children. Besides, the statistically non-significant difference according to gender on Physical Abuse Signs Rating Scale's states, behavioral characteristics and parent behaviors subtest scores was similar in studies carried out by Uysal and Özsoy (2003), Tugay (2008) and Pala (2011). Moreover in this study it was concluded that pre-service teachers who were trained and qualified on identifying child neglect and abuse were more successful at evaluating physical abuse signs. In parallel with this finding, Kenny (2004), Webster, O’Toole, O’Toole and Lucal (2005) and Goebbels, Nicholson, Walsh and De Vries (2008) also found out that such training was effectual in the identification of child neglect and abuse. According to the conclusions drawn, in order to prevent child neglect and abuse which is a crucial social issue, the authors suggest the development of interdisciplinary cooperation during both the pre-service and in-service child neglect and abuse identification training of teachers who are the most responsible ones apart from the parents since the children spend most of their time at school. 


\section{Öğretmen Adaylarının Çocuklardaki Fiziksel İstismar Belirtilerine İlişkin Farkındalıkları*}

Münevver CAN-YAŞAR**
Gözde INAL KIZILTEPE***

\author{
Adalet KANDIR****
}

Makale Gönderme Tarihi: 03 Aralık 2013

Makale Kabul Tarihi: 21 Şubat 2014

ÖZET: Öğretmen adaylarının çocuklardaki fiziksel istismar belirtilerine ilişkin farkındalık düzeylerinin incelenmesi amacıyla yapılan araştırmanın çalışma grubuna, Afyon Kocatepe Üniversitesi Eğitim Fakültesi’nde öğrenim gören 764 öğretmen adayı dahil edilmiştir. Araştırmada veri toplama aracı olarak, öğretmen adaylarının demografik özelliklerinin yer aldığı genel bilgi formu ve Erol (2007) tarafından geliştirilen "Fiziksel İstismar Belirtileri Değerlendirme Formu" kullanılmıştır. Araştırmanın sonucunda, öğretmen adaylarının cinsiyetleri, branşları ve sınıf düzeylerine göre Fiziksel İstismar Belirtilerini Değerlendirme Formu'nun durum, davranışsal özellikler ve anne baba davranışları bölüm puanları arasında istatistiksel olarak anlamlı derecede farklılığın olmadığı, öğretmen adaylarının çocuk ihmal ve istismarına yönelik eğitim alma durumlarına göre ise Fiziksel İstismar Belirtilerini Değerlendirme Formu'nun durum ve davranışsal özellikler puan değerleri açısından istatistiksel olarak anlamlı derecede farklılık olduğu belirlenmiştir.

Anahtar sözcükler: çocuk ihmal ve istismarı, fiziksel istismar, öğretmen adayları

\section{Giriş}

Son yıllarda çocuk ihmal ve istismarı gerek tıbbi, gerekse toplumsal açıdan giderek önem kazanmaya başlamış bir sorundur. Konunun yeterince bildirilmemesi, tanı konulmasındaki güçlükler, inkâr edilmesi ve gizli kalması sorunun önemini daha da artırmaktadır. Dünya Sağlık Örgütü’nün verilerinde, dünyada 1-14 yaş grubundaki 40 milyon çocuğun ihmal ve istismara uğradığ ve desteğe gereksinimi olduğu belirtilmektedir (Erol, 2007; Pala, 2011). Amerika Ulusal Çocuk İhmal ve İstismarı Veri Sistemi Raporları'na göre (The National Child Abuse and Neglect Data System Reports) 2005 yilında raporlanan 1460 çocuk ölümü, çocuk ihmal ve istismarından kaynaklanmaktadır. Çocuk ihmal ve istismarına bağlı ölüm olguları incelendiğinde; $\% 38$ 'inin ihmalden, \%30'unun fiziksel istismardan diğerlerinin ise birden fazla ihmal ve istismardan kaynaklandığı belirlenmiştir (U.S. Department of Health and Human Services, 2011).

Çocuk istismarı, dünyadaki birçok bilim literatüründe yer alan bir olgu olmakla beraber çeşitli toplumlarda ve kültürlerde farklı şekillerde algılanmakta ve tanımlanmaktadır (Atamer, 2005; Lau ve diğerleri, 2006). Dünya Sağlık Örgütü (World Health Organization) (1985) "çocuğun sağlı̆̆ını, fiziksel gelişimini olumsuz yönde etkileyen-bir yetişkin, topluluk ya da ülke tarafindan- bilerek ya da bilmeyerek yapılan davranışları" çocuk istismarı olarak tanımlanmaktadır (Akt. Gündüz \& Gökçakan,

\footnotetext{
* Bu makale, 27-28-29 Nisan 2012 tarihlerinde Gaziantep’te Zirve Üniversitesi tarafindan düzenlenen Erken Çocukluk Eğitimi Küresel Sorunları ve Çocuk Hakları Uluslararası Konferansı'nda sözlü bildiri olarak sunulmuştur. ** Doç. Dr., Afyon Kocatepe Üniversitesi, Eğitim Fakültesi, Afyonkarahisar, Türkiye, munevver2002@yahoo.com ***Sorumlu Yazar: Yrd. Doç. Dr, Adnan Menderes Üniversitesi, Eğitim Fakültesi, Aydın, Türkiye, gozde.kiziltepe@adu.edu.tr

**** Prof. Dr., Gazi Üniversitesi, Eğitim Fakültesi, Ankara, Türkiye, akandir@gmail.com
} 
2004). Polat (2007) ise çocuk istismarını, "0-18 yaş grubundaki çocuğun; kendisine bakmakla yükümlü kişi veya kişiler tarafından zarar verici olan, kaza dışı ve önlenebilir, çocuğun fiziksel ve psiko-sosyal gelişimini engelleyen, gerçekleştiği toplumun kültür değerleri dışında kalan ve uzmanlar tarafindan istismar olarak kabul edilen bir davranışa maruz kalması" şeklinde tanımlamaktadır. Çocuk istismarının kendi içinde farklı biçimleri bulunmaktadır. Dünya Sağlık Örgütü'ne (1999) göre bunlar; cinsel istismar, duygusal istismar, ekonomik istismar ve fiziksel istismardır (Akt. Bahar, Savaş ve Bahar, 2009; Pala, 2011).

Çok yaygin olarak karşılaşılan ve belirlenmesi en kolay istismar türü olan fiziksel istismar, çocukların onlara bakmakla yükümlü olan kişiler tarafından fiziksel açıdan zarar görerek bedensel bütünlüğünün bozulmasıdır. Çocuklarda fiziksel bir hasara ve yaralanmaya yol açan ve hatta ölüme neden olabilen tüm erişkin davranışları fiziksel istismar içinde yer almaktadır. Fiziksel istismarın çocuk üzerindeki etkileri kısa ve uzun dönemde olmak üzere iki grupta ele alınmaktadır. Kısa dönemdeki etkiler morluklar, yaralar, kırıklar vb. biçimlerde olurken, uzun dönemdeki etkilerin ise psikolojik ve sosyal yönde olduğu görülmektedir (Hilal, 2005; Polat, 2007; Yolcu, 2009; Wood ve Ludwig, 2010).

Fiziksel istismar, öncelikle aile ortamında ortaya çıkan ancak süreç içerisinde çocuk bakımından sorumlu olan diğer ortamlarda da kendini gösteren bir sorundur. $\mathrm{Bu}$ nedenle çocukların ev ortamı dışında en çok zaman geçirdikleri yer olan okul ortamı, istismara uğrayan çocuk ve ergenlerin tespit edilmesi ve istismarın önlenmesi açısından büyük önem taşımaktadır. İstismar olgularında okulun görevleri "tanımlama", "değerlendirme" ve "yönlendirme" olmak üzere üç grupta toplanmaktadır. Bu görevlerin yerine getirilmesinde, öğretmenlere önemli sorumluluklar düşmektedir (Kenny, 2001; Erol, 2007). Toplumsal etkileri, eğitimci kimlikleri, yasal, mesleki ve kişisel sorumlukları nedeniyle öğretmenlerin istismarı önleme ve belirleme çalışmalarında yer almaları gerekmektedir. Tüm gün çocuklarla birlikte olan, onların özelliklerini iyi tanıyan öğretmenler, çocuklarda meydana gelebilecek davranış değişikliklerini tanıma ve tanımlama şansına sahiptirler (Baginsky, 2003; CrossonTower, 2003). Bu nedenle de çocuk ihmal ve istismarı olgularının belirlenmesinde ve önlenmesinde öğretmenlerin rolü çok önemlidir. İlgili alan yazında yer alan araştırmalarda da; öğretmenlerin çocuklarla sürekli iletişim halinde olmaları, çocuk eğitimi ile ilgili bilgi ve deneyime sahip olmaları nedeniyle, aileleri tarafından kötü muameleye maruz kalan çocukların belirlenmesinde ve korunmasında özel bir öneme sahip oldukları vurgulanmaktadır (O’Toole, Webster, O’Toole ve Lucal, 1999; Webb ve Vulliamy, 2001; Yolcu, 2009; Pala, 2011).

Anne babadan sonra çocukların hayatında önemli bir yeri olan öğretmenlerin istismar olgularını tespit etmede rol almaları gereği, öğretmenlerin çocuk ihmal ve istismarı konusunda eğitilmeleri gereğini de beraberinde getirmektedir (Goldman, 2005; Walsh, Bridgstock, Farrell ve Schweitzer, 2005). Bununla birlikte öğretmenlerin; mesleki bilgi ve becerilerini geliştirmeleri ve çocukları koruyucu davranışları öğrenebilmeleri için, çocuk ihmal ve istismarı ile ilgili hizmet öncesi eğitim almaları 
gerekmektedir. Bu noktadan hareketle araştırmada, öğretmen adaylarının çocuklardaki fiziksel istismar belirtilerine ilişkin farkındalık düzeylerinin incelenmesi amaçlanmıştır.

\section{Yöntem}

$\mathrm{Bu}$ araştırma; öğretmen adaylarının çocuklardaki fiziksel istismar belirtilerine ilişkin farkındalık düzeylerinin cinsiyet, bölüm, sınıf ve çocuk ihmal ve istismarına yönelik eğitim alma değişkenlerine göre farklılık gösterip göstermediğini ortaya koyduğundan betimsel nitelikte olup, tarama modeli tipindedir (Büyüköztürk, KılıçÇakmak, Akgün, Karadeniz ve Demirel, 2011).

\section{Evren ve Örneklem}

Araştırmanın çalışma evrenini, 2011-2012 eğitim öğretim yılında Afyon Kocatepe Üniversitesi Eğitim Fakültesi'nde öğrenim gören birinci ve dördüncü sınıf öğretmen adayları oluşturmaktadır. Çalışma evreni oluşturan 904 öğretmen adayının 173'ü (1.Sınıf: 116, 4.Sınıf: 57) Okul Öncesi Öğretmenliği Anabilim Dalı'nda, 305'i (1.Sınıf: 153, 4.Sınıf: 152) Sınıf Öğretmenliği Anabilim Dalı'nda, 289'u (1.Sınıf: 151, 4.Sınıf: 138) Sosyal Bilgiler Öğretmenliği Anabilim Dalı'nda, 137'si (1.Sınıf: 90, 4.Sınıf: 47) Türkçe Eğitimi Bölümü'nde öğrenim görmektedir. Araştırmanın çalışma evreninin büyük olmaması ve araştırmada ulaşabilme kolaylığı nedeniyle araştırmada örneklem alma yoluna gidilmemiş, araştırma evreni aynı zamanda araştırmanın çalışma grubu olarak kabul edilmiştir. Araştırmada gönüllülük esas alındığından evren içerisinden 140 öğretmen adayı çalışma grubunun dışında kalmıştır. Buna göre araştırmanın çalışma grubunu, Eğitim Fakültesi Okul Öncesi Öğretmenliği Anabilim Dalı'ndan 173, Sınıf Öğretmenliği Anabilim Dalı'ndan 241, Sosyal Bilgiler Öğretmenliği Anabilim Dalı'ndan 221, Türkçe Eğitimi Bölümü’nden 129 olmak üzere toplam 764 öğretmen adayı oluşturmuştur.

Araştırmaya katılan öğretmen adaylarının demografik özellikleri incelendiğinde; \%65.05'inin kı, \%34.95'inin erkek olduğu; \%50.13'ünün 17-20 yaş aralığında, \%47.91'inin 21-25 yaş aralığında, \%1.96'sının ise 26-30 yaş aralığında olduğu; öğretmen adaylarının \%78.14'ünün daha önce çocuk ihmal ve istismarına yönelik eğitim almadığı, \%21.86'sının ise eğitim aldığı belirlenmiştir.

\section{Veri Toplama Araçları}

Araştırmada veri toplama aracı olarak, öğretmen adaylarının demografik özelliklerinin yer aldığı genel bilgi formu ve araştırma probleminin çözümü için gerekli bilgileri toplamada "Fiziksel İstismar Belirtileri Değerlendirme Formu” kullanılmıştır.

Genel Bilgi Formu. Araştırmacılar tarafından geliştirilen formda; öğretmen adaylarının cinsiyeti, yaşı, daha önce çocuk ihmal ve istismarına yönelik eğitim alma durumu, çocuk ihmal ve istismarı konusunda bilgi edinme kaynakları, çocuk ihmal ve istismarının bildirilmesi, Çocuk Koruma Kanunu hakkında bilgi sahibi olma durumu ve fiziksel istismar belirtilerini tanımlamada kendisini hazır hissetme durumuna ilişkin çoktan seçmeli sorular yer almaktadır. 
Fiziksel İstismar Belirtileri Değerlendirme Formu (FİBDF). Erol (2007) tarafından geliştirilen form iki bölümden oluşmaktadır. Birinci bölüm, fiziksel istismar belirtilerine ilişkin durum (10 madde), davranışsal özellikler (4 madde) ve anne baba davranışları (5 madde) olmak üzere toplam 19 maddeden, ikinci bölüm ise aynı şekilde fiziksel istismar belirtilerine ilişkin durum (10 madde), davranışsal özellikler (4 madde) ve anne baba davranışları (5 madde) ile öğretmenlerin bu durumlarla karşılaşma sıklığını öğrenmeyi amaçlayan toplam 19 maddeden oluşmaktadır. Formun birinci bölümündeki soruların yanıtları; "evet" ve "hayır" olmak üzere ikili derecelemeye göre, ikinci bölümdeki soruların yanıtları ise "sıklıkla", "ara sıra" ve "hiç" olmak üzere üçlü derecelemeye göre düzenlenmiştir. Yapılan güvenirlik çalışmasında formun güvenirlik katsayısı .95 olarak belirlenmiştir.

Araştırma öğretmen adaylarının çocuklardaki fiziksel istismar belirtilerine ilişkin farkındalık düzeylerini incelemeyi amaçladığından, araştırmada Fiziksel İstismar Belirtileri Değerlendirme Formu'nun yalnız birinci bölümü kullanılmıştır.

\section{Verilerin Analizi}

Elde edilen verilerin analizinde; öğretmen adaylarına ilişkin demografik özelliklerin değerlendirilmesinde frekans ve yüzde gibi betimsel istatistikler kullanılmıştır. Öğretmen adaylarının Fiziksel İstismar Belirtileri Değerlendirme Formu'ndan elde edilen verilerin normallik testi [Kolmogorov-Smirnoff (K-S)] sonucunda; gruplar arası farklılık incelenirken ikili gruplarda Mann Whitney U Testi, ikiden fazla gruplarda ise Kruskal Wallis H Testi uygulanmıştır. Gruplar arası farklılık incelenirken; anlamlılık seviyesi olarak .05 kullanılmış olup $\mathrm{p}<.05$ olması durumunda gruplar arası anlamlı farklılığın olduğu, $\mathrm{p}>.05$ olması durumunda ise gruplar arası anlamlı farklılığın olmadığı belirtilmiştir (Büyüköztürk ve diğerleri, 2011).

\section{Bulgular}

Öğretmen adaylarının çocuklardaki fiziksel istismar belirtilerine ilişkin farkındalık düzeylerinin incelenmesi amacıyla yapılan araştırmada, öğretmen adaylarının çocuk ihmal ve istismarı ile ilgili sorulara verdikleri yanıtların dağılımı Tablo 1'de verilmiştir. 
Tablo 1

Öğretmen adaylarının çocuk ihmal ve istismarı ile ilgili sorulara verdikleri yanıtların dă̆ılımı

\begin{tabular}{|c|c|c|c|}
\hline Çocuk İhmal ve İstismarına İlişkin Görüşler & Yanitlar & $N$ & $\%$ \\
\hline $\begin{array}{l}\text { Kanunlara göre çocuk ihmal ve istismarı şüphesini } \\
\text { bildirme }\end{array}$ & $\begin{array}{c}\text { Evet } \\
\text { Hayir } \\
\text { Toplam }\end{array}$ & $\begin{array}{c}730 \\
34 \\
764\end{array}$ & $\begin{array}{c}95.5 \\
5 \\
4.45 \\
100\end{array}$ \\
\hline $\begin{array}{l}\text { Milli Eğitim Politikaları'na göre profesyonel anlamda } \\
\text { çocuk ihmal ve istismarı şüphesini bildirme }\end{array}$ & $\begin{array}{c}\text { Evet } \\
\text { Hayır } \\
\text { Toplam }\end{array}$ & $\begin{array}{c}687 \\
77 \\
764\end{array}$ & $\begin{array}{c}89.9 \\
2 \\
10.0 \\
8 \\
100\end{array}$ \\
\hline $\begin{array}{l}\text { Etik açıdan çocuk ihmal ve istismarı şüphesini } \\
\text { bildirme }\end{array}$ & $\begin{array}{c}\text { Evet } \\
\text { Hayır } \\
\text { Toplam }\end{array}$ & $\begin{array}{c}747 \\
17 \\
764\end{array}$ & $\begin{array}{c}97.7 \\
7 \\
2.23 \\
100 \\
\end{array}$ \\
\hline $\begin{array}{l}\text { Çocuk ihmal ve istismarı durumunu tespit } \\
\text { edildiğinde bildirim yapılması gereken kurumlar }\end{array}$ & $\begin{array}{l}\text { Sosyal Hizmetler Müdürlüğü } \\
\text { Milli Eğitim Müdürlüğü } \\
\text { Sağlık Müdürlüğü } \\
\text { Emniyet Müdürlüğü } \\
\text { Okul Aile Birliği } \\
\text { Okul Yönetimi } \\
\text { Toplam }\end{array}$ & $\begin{array}{c}140 \\
20 \\
6 \\
\\
515 \\
11 \\
72 \\
764\end{array}$ & $\begin{array}{c}18.3 \\
2 \\
2.62 \\
0.79 \\
67.4 \\
1 \\
1.44 \\
9.42 \\
100\end{array}$ \\
\hline Çocuk Koruma Kanunu hakkında bilgi sahibi olma & $\begin{array}{l}\text { Evet } \\
\text { Hayır } \\
\text { Toplam }\end{array}$ & $\begin{array}{l}109 \\
655 \\
764\end{array}$ & $\begin{array}{c}14.2 \\
7 \\
85.7 \\
3 \\
100\end{array}$ \\
\hline $\begin{array}{l}\text { Fiziksel istismarın belirtilerini tanımlamada kendini } \\
\text { hazır hissetme }\end{array}$ & $\begin{array}{c}\text { Hazırlıksız } \\
\text { Kısmen Hazırlıksız } \\
\text { Emin Değil } \\
\text { Kısmen Hazırlıklı } \\
\text { Hazırlıklı } \\
\text { Toplam }\end{array}$ & $\begin{array}{c}247 \\
25 \\
764\end{array}$ & $\begin{array}{c}15.9 \\
7 \\
9.42 \\
39.0 \\
1 \\
32.3 \\
3 \\
3.27 \\
100\end{array}$ \\
\hline
\end{tabular}

Tablo 1 incelendiğinde, araştırmaya katılan öğretmen adaylarının \%95.55'inin kanunlara göre, \%89.92'sinin Milli Eğitim politikalarına göre, \%97.77'sinin ise etik anlamda çocuk ihmal ve istismarı şüphesini bildirme sorumlulukları olduğunu düşündükleri; \%67.41'inin çocuk ihmal ve istismarı durumunu Emniyet Müdürlüğü'ne, \%18.02'sinin ise Sosyal Hizmetler Müdürlügü'ne bildirmeleri gerektiklerini düşündükleri; \%85.73’ünün Çocuk Koruma Kanunu hakkında bilgisinin olmadığ1; \%39.01'inin ise fiziksel istismarın belirtilerini tanımlama konusunda kendilerinden emin olmadıkları görülmektedir. 
Öğretmen adaylarının cinsiyetlerine göre Fiziksel İstismar Belirtilerini Değerlendirme Formu puanlarına ilişkin Mann Whitney U Testi sonuçları Tablo 2'de verilmiştir.

Tablo 2

Öğretmen adaylarının cinsiyetlerine göre Fiziksel İstismar Belirtilerini Değerlendirme Formu puanlarına ilişkin Mann Whitney U Testi sonuçları

\begin{tabular}{|c|c|c|c|c|c|}
\hline \multirow{2}{*}{ FİBDF } & \multirow{2}{*}{ Cinsiyet } & \multirow{2}{*}{$\mathrm{N}$} & \multirow{2}{*}{ Sira Ort. } & \multicolumn{2}{|c|}{ Mann Whitney U Test } \\
\hline & & & & $U$ & $p$ \\
\hline \multirow[t]{2}{*}{ Durum } & Kiz & 497 & 389.38 & \multirow{2}{*}{62932} & \multirow{2}{*}{.200} \\
\hline & Erkek & 267 & 369.70 & & \\
\hline \multirow[t]{2}{*}{ Davranışsal Özellikler } & $\mathrm{K} 1 \mathrm{z}$ & 497 & 392.25 & \multirow{2}{*}{61501.5} & \multirow{2}{*}{.059} \\
\hline & Erkek & 267 & 364.34 & & \\
\hline \multirow[t]{2}{*}{ Anne Baba Davranışları } & $\mathrm{K} 1 \mathrm{z}$ & 497 & 407.61 & \multirow{2}{*}{59645.5} & \multirow{2}{*}{.013} \\
\hline & Erkek & 267 & 369.01 & & \\
\hline
\end{tabular}

Tablo 2 incelendiğinde, öğretmen adaylarının cinsiyetleri ile Fiziksel İstismar Belirtilerini Değerlendirme Formu'nun durum ( $\mathrm{U}=62932, \mathrm{p}>.05)$, davranışsal özellikler $(\mathrm{U}=61501.5, \mathrm{p}>.05)$ ve anne baba davranışları $(\mathrm{U}=59645.5, \mathrm{p}>.05)$ bölüm puanları arasında istatistiksel olarak anlamlı derecede farklılık görülmemektedir. Bu sonuca göre, her iki cinsiyetin de fiziksel istismarın belirtilerini değerlendirmede benzer özellikler sergilediği söylenebilir.

Öğretmen adaylarının öğretmenlik alanlarına göre Fiziksel İstismar Belirtilerini Değerlendirme Formu puanlarına ilişkin Kruskal Wallis H Testi sonuçları Tablo 3'te verilmiştir.

Tablo 3

Öğretmen adaylarının öğretmenlik alanlarına göre Fiziksel İstismar Belirtilerini Değerlendirme Formu puanlarına ilişkin Kruskal Wallis H Testi sonuçları

\begin{tabular}{|c|c|c|c|c|c|c|}
\hline \multirow{2}{*}{ FİBDF } & \multirow{2}{*}{ Bölüm } & \multirow{2}{*}{$N$} & \multirow{2}{*}{ Stra Ort. } & \multirow{2}{*}{ sd } & \multicolumn{2}{|c|}{ Kruskal Wallis H Testi } \\
\hline & & & & & $H$ & $p$ \\
\hline \multirow{4}{*}{ Durum } & Okul Öncesi Öğretmenliği & 173 & 397.97 & \multirow{4}{*}{3} & \multirow{4}{*}{2.162} & \multirow{4}{*}{.540} \\
\hline & Sınıf Öğretmenliği & 241 & 393.76 & & & \\
\hline & Sosyal Bilgiler Öğretmenliği & 221 & 376.15 & & & \\
\hline & Türkçe Eğitimi Öğretmenliği & 129 & 371.96 & & & \\
\hline \multirow{4}{*}{$\begin{array}{l}\text { Davranışsal } \\
\text { Özellikler }\end{array}$} & Okul Öncesi Öğretmenliği & 173 & 393.42 & \multirow{4}{*}{3} & \multirow{4}{*}{1.518} & \multirow{4}{*}{.678} \\
\hline & Sinıf Öğretmenliği & 241 & 387.05 & & & \\
\hline & Sosyal Bilgiler Öğretmenliği & 221 & 373.45 & & & \\
\hline & Türkçe Eğitimi Öğretmenliği & 129 & 374.60 & & & \\
\hline \multirow{4}{*}{$\begin{array}{l}\text { Anne Baba } \\
\text { Davranışları }\end{array}$} & Okul Öncesi Öğretmenliği & 173 & 404.62 & \multirow{4}{*}{3} & \multirow{4}{*}{4.072} & \multirow{4}{*}{.254} \\
\hline & Sinıf Öğretmenliği & 241 & 383.91 & & & \\
\hline & Sosyal Bilgiler Öğretmenliği & 221 & 372.88 & & & \\
\hline & Türkçe Eğitimi Öğretmenliği & 129 & 368.37 & & & \\
\hline
\end{tabular}


Tablo 3 incelendiğinde, öğretmen adaylarının öğretmenlik alanları ile Fiziksel İstismar Belirtilerini Değerlendirme Formu'nun durum $(\mathrm{H}=2.162, \mathrm{p}>.05)$, davranışsal özellikler $(\mathrm{H}=1.518, \mathrm{p}>.05)$ ve anne baba davranışları $(\mathrm{H}=4.072, \mathrm{p}>.05)$ bölüm puanları arasında istatistiksel olarak anlamlı derecede farklılık görülmemektedir. İstatistiksel olarak anlamlı farklılık görülmemekle birlikte, durum, davranışsal özellikler ve anne baba davranışları bölümlerinde okul öncesi öğretmenliği alanında öğrenim gören öğretmen adaylarının sıra ortalamalarının diğer alanlarda öğrenim gören öğretmen adaylarından daha yüksek olduğu görülmektedir.

Öğretmen adaylarının sınıf düzeylerine göre Fiziksel İstismar Belirtilerini Değerlendirme Formu puanlarına ilişkin Mann Whitney U Testi sonuçları Tablo 4'te verilmiştir.

Tablo 4

Öğretmen adaylarının sinıf düzeylerine göre Fiziksel İstismar Belirtilerini Değerlendirme Formu puanlarına ilişkin Mann Whitney U Testi sonuçları

\begin{tabular}{llcccc}
\hline \multirow{2}{*}{ FiBDF } & \multirow{2}{*}{ Sinıf } & \multirow{2}{*}{$N$} & Sira Ort. & \multicolumn{2}{c}{ Mann Whitney U Testi } \\
\cline { 6 - 7 } Durum & 1. Sınıf & 445 & 360.45 & \multirow{2}{*}{61163.5} & $.000^{*}$ \\
\multirow{2}{*}{ Davranışsal Özellikler } & 4. Sınıf & 319 & 413.26 & & \\
\multirow{2}{*}{ Anne Baba Davranışları } & 1. Sınıf & 445 & 365.38 & \multirow{2}{*}{63361} & $.004^{*}$ \\
& 4. Sınıf & 319 & 406.38 & & \multirow{2}{*}{. } \\
& 1. Sınıf & 445 & 378.74 & \multirow{2}{*}{69304} &. \\
\hline
\end{tabular}

${ }^{*} \mathrm{p}<.05$

Tablo 4 incelendiğinde, öğretmen adaylarının sınıf düzeylerine göre Fiziksel İstismar Belirtilerini Değerlendirme Formu'nun durum ( $U=61163.5, \quad p<.05)$ ve davranışsal özellikler $(\mathrm{U}=63361, \mathrm{p}<.05)$ puan değerleri açısından istatistiksel olarak anlamlı derecede farklılık görülmektedir. Öğretmen adaylarının sınıf düzeylerine göre Fiziksel İstismar Belirtilerini Değerlendirme Formu'nun anne baba davranışları $(\mathrm{U}=69304, \mathrm{p}>05)$ puan değerleri açısından ise istatistiksel olarak anlamlı derecede farklılık görülmemektedir. Ancak öğretmen adaylarının durum, davranışsal özellikler ve anne baba davranışları sıra ortalamalarının 4. sınıf öğretmen adaylarında 1.sınıf öğretmen adaylarına göre daha yüksek olduğu da dikkati çekmektedir.

Öğretmen adaylarının çocuk ihmal ve istismarı ile ilgili eğitim alma durumuna göre Fiziksel İstismar Belirtilerini Değerlendirme Formu puanlarına ilişkin Mann Whitney U Testi sonuçları Tablo 5'te verilmiştir. 
Tablo 5

Öğretmen adaylarının çocuk ihmal ve istismart ile ilgili ĕgitim alma durumuna göre Fiziksel İstismar Belirtilerini Değerlendirme Formu puanlarına ilişkin Mann Whitney U Testi sonuçları

\begin{tabular}{llrrrr}
\hline \multirow{2}{*}{ FİBDF } & $\begin{array}{c}\text { Çocuk ihmal ve istismarı ile } \\
\text { ilgili eğitim alma durumu }\end{array}$ & $N$ & Sira Ort. & \multicolumn{2}{c}{ Mann Whitney U Testi } \\
\cline { 5 - 6 } Durum & Eğitim alan & 167 & 411.66 & 44980 & $.035^{*}$ \\
Davranışsal & Eğitim almayan & 597 & 374.34 & & \\
Özellikler & Eğitim alan & 167 & 422.63 & 43148.5 & $.003^{*}$ \\
Anne Baba & Eğitim almayan & 597 & 371.28 & & .152 \\
Davranışları & Eğitim alan & 167 & 402.64 & 46485.5 & .152 \\
\hline
\end{tabular}

Tablo 5 incelendiğinde, öğretmen adaylarının çocuk ihmal ve istismarına yönelik eğitim alma durumlarına göre Fiziksel İstismar Belirtilerini Değerlendirme Formu'nun durum $(\mathrm{U}=44980, \mathrm{p}<.05)$ ve davranışsal özellikler $(\mathrm{U}=43148.5, \mathrm{p}<.05)$ puan değerleri açısından istatistiksel olarak anlamlı derecede farklılık görülmektedir. Öğretmen adaylarının çocuk ihmal ve istismarına yönelik eğitim alma durumlarına göre Fiziksel İstismar Belirtilerini Değerlendirme Formu'nun anne baba davranışları $(\mathrm{U}=46485.5, \mathrm{p}>.05)$ puan değerleri açısından ise istatistiksel olarak anlamlı derecede farklılık görülmemektedir. Sıra ortalamaları dikkate alındığında çocuk ihmal ve istismarına yönelik eğitim alan öğretmen adaylarının eğitim almayanlara göre fiziksel istismarın belirtilerini değerlendirmede daha yeterli olduğu ortaya çıkmaktadır.

\section{Sonuç ve Tartışma}

Öğretmen adaylarının çocuklardaki fiziksel istismar belirtilerine ilişkin farkındalık düzeylerinin incelenmesi amacıyla yapılan araştırmada, öğretmen adaylarının \%95.55’inin kanunlara göre, \%89.92'sinin Milli Eğitim politikalarına göre, \%97.77'sinin ise etik anlamda çocuk ihmal ve istismarı şüphesini bildirme sorumlulukları olduğunu düşündükleri; \%67.41'inin çocuk ihmal ve istismarı durumunu Emniyet Müdürlüğü’ne, \%18.02'sinin ise Sosyal Hizmetler Müdürlüğü’ne bildirmeleri gerektiklerini düşündükleri; \%85.73’ünün Çocuk Koruma Kanunu hakkında bilgisinin olmadığ1; \%39.01'inin fiziksel istismarın belirtilerini tanımlama konusunda kendilerinden emin olmadıkları belirlenmişstir (Tablo 1). Türkiye'de 2001 Türk Medeni Kanunu’nda, 2002 Çocuk Haklarına Dair Ek Sözleşme'de, 2003 İş Kanunu'nda, 2005 Çocuk Koruma Kanunu'nda ve 2006 Çocuk Koruma Kanunu'nun Uygulanmasına İlişkin Usul ve Esaslar Hakkında Yönetmelik’te çocukların her türlü kötü muameleden korunmasına ilişkin maddeler yer almaktadır. Türkiye 1995 yılında Çocuk Hakları Sözleşmesi'ni Resmi Gazete'de yayınlayarak kabul etmiş ve bu çerçevede çocuğun yasal vasi veya vasilerinin ya da bakımını üstlenen herhangi bir kişinin yanında iken her türlü istismar ve kötü muameleye karşı korunması için; yasal, idari, toplumsal, eğitsel bütün önlemleri alma sorumluluğunu üstlenmiştir. Milli Eğitim politikaları incelendiğinde ise Milli Eğitim Bakanlığ İlköğretim ve Eğitim Kanunu, Milli Eğitim 
Temel Kanunu ve daha pek çok yasa ve yönetmeliklerde çocuk istismarı ile ilgili hükümler yer almaktadır (Tıraşçı ve Gören, 2007; Tugay, 2008; Pala, 2011).

Tugay (2008) tarafından yapılan çalışmada öğretmenlerin \%51,2'sinin kanunlara göre, \%45.7'sinin Milli Eğitim politikalarına göre, \%85.2'sinin ise etik açıdan çocuk ihmal ve istismarını bildirme zorunlulukları olduğuna inandıkları tespit edilmiştir. Amerika'da çocuk ihmal ve istismarının bildirilmesi ile ilgili yasal olarak zorunlulukların yanında açık bir şekilde eğitimcilere yönelik olarak belirtilmiş eğitim politikaları da bulunmaktadır. Buna rağmen, Kenny (2004) tarafından Amerika'da yapılan bir çalışmada öğretmenlerin \%85'inin yasalara göre çocuk ihmal ve istismarını bildirim zorunluluğunun farkında olmadıkları sonucu ortaya çıkmıştır. Yapılan diğer çalışmalarda da profesyoneller tarafından tanımlanan ihmal ve istismar olgularının \%69'unun çocuk koruma servislerine bildirilmediği (Stein, 1984) ve \%40 oranında ise bildirim zorunluluğu ile ilgili yasaya uymadığı belirlenmiştir. Bildirimde bulunulmamasının bazı nedenleri dava edilme veya karşılık görme korkusu, çocuk koruma servislerine yeterli güven duyulmaması, etik açıdan sakınca olduğu, klinik kanıt veya bildirilmiş kanıtın yetersiz olduğunu düşünme, çocuğun ve ailenin zarar göreceği endişesidir (Reiniger, Robison ve McHugh, 1995). Tablo 1'de öğretmen adaylarının büyük bir çoğunluğunun henüz öğretmen olmadan önce kanunlara ve Milli Eğitim politikalarına göre çocuk ihmal ve istismarını bildirme zorunluluklarının olduğunun farkında olmaları dikkate değer bir sonuçtur.

Çocuklarla çalışan uzmanların ve eğitimcilerin çoğu ne zaman, nasıl ve nereye bildirimde bulunacağını bilmemektedirler. Çocuk ve ergen vakalar için bildirim tartışmasız koruyucu bir yaklaşımdır. İstismarcıların çoğunun aile içinden ya da tanıdık biri olduğu bilinmektedir (Yolga-Tahiroğlu, Avcı ve Çekin, 2008). Aile içinde ya da yakın çevrede istismar edilen ve kendini koruyamayan bir çocuğun ortamdan uzaklaştırılması tedaviden çok daha önceliklidir. Adli bildirim çocukları korumanın yanı sıra tedaviyi de desteklemektedir (Çelik, Yolga-Tahiroğlu, Avcı, Meral ve Çekin, 2007). Sağlık çalışanları ve kamu görevlilerin çocuklarda ihmal veya istismar belirtisi gördükleri zaman Türk Ceza Kanunu'nun 278-279-280. maddelerine göre bildirim yükümlülüğü bulunmaktadır (T.C. Resmi Gazete, 2005). İhmal ve istismar kuşkusunda bildirimde bulunulabilecek kuruluşlar; hastanelerin çocuk koruma birimleri/merkezleri, Aile ve Sosyal Politikalar Bakanlığı'na bağlı Çocuk Hizmetleri Genel Müdürlüğü (eski adıyla; Sosyal Hizmetler ve Çocuk Esirgeme Kurumu), bölge polis karakolu (çocuk polisi), Cumhuriyet Savcılığı ve Alo 183 Aile, Kadın, Çocuk ve Özürlü Sosyal Hizmet Danışma Hattı şeklinde sıralanmaktadır. Tablo 1'de öğretmen adaylarının çoğunluğunun ihmal ve istismar şüphesi veya tespiti karşısında bildirim yapacağ kuruluşu Emniyet Müdürlüğü $(\% 67,41)$ olarak belirtmesi olumlu yarg1 gibi görünmekle birlikte bu sonuç, genel sıralama düşünüldüğünde öğretmen adaylarının ne zaman, nasıl ve nereye bildirimde bulunacakları konusunda desteğe gereksinimleri olduğunu da göstermektedir.

Tugay (2008) çalışmasında öğretmenlerin istismar türlerine göre (fiziksel, duygusal ve cinsel) çocuk istismarını belirlemede toplam güven ortalamalarının yüksek 
olmaması (3.46) sonucunu, öğretmenlerin tüm ihmal ve istismar belirtilerini tanımlama konusunda kendilerinden tam olarak emin olmamalarına bağlamaktadır. Walsh ve diğerleri (2005) tarafından Avustralya'da yapılan çalışmada da öğretmenlerin tüm ihmal ve istismar belirtilerini tanımlama konusunda kendilerinden emin olmadikları sonucu ortaya çıkmıştır. Kenny (2004) tarafindan yapılan çalışmada ise öğretmenlerin \%81'i fiziksel istismarı tanımlamada hazırlıksız olduklarını belirtmişlerdir. Pala (2011) tarafından yapılan çalışmada da fiziksel istismarın, öğretmen adaylarının istismar belirtilerini tanımlamada kendilerini en çok hazırlıksız hissettikleri ikinci istismar türü olduğu tespit edilmiştir. Tablo 1'de öğretmen adaylarının çoğunluğunun fiziksel istismarın belirtilerini tanımlama konusunda kendilerinden emin olmamaları sonucu, ilgili alan yazındaki araştırma sonuçları ile paralellik göstermektedir.

Araştırmada, öğretmen adaylarının cinsiyetleri göre Fiziksel İstismar Belirtilerini Değerlendirme Formu'nun durum, davranışsal özellikler ve anne baba davranışları bölüm puanları arasında istatistiksel olarak anlamlı derecede farklılığın olmadığı belirlenmiştir (Tablo 2). Uysal ve Özsoy’un (2003) öğretmenlerin çocuk ihmal ve istismarına ilişkin görüş ve tutumlarını inceledikleri araştırmalarında, öğretmenlerin cinsiyetleri ile çocuk ihmal ve istismarına ilişkin oluşturulmuş öykülere verdikleri puan ortalamaları arasında istatistiksel açıdan anlamlı bir ilişkinin olmadığı sonucu ortaya çıkmıştır. Benzer şekilde Tugay (2008) tarafından yapılan araştırmada öğretmenlerin cinsiyetlerinin çocuk ihmal ve istismarını belirlemeye yönelik etkisinin olmadığı tespit edilmiştir. Pala'nın (2011) öğretmen adayları ile yaptığı çalışmada da öğretmen adaylarının cinsiyetleri ile çocuk ihmal ve istismarı konusundaki bilgi ve farkındalık düzeyleri arasında istatistiksel açıdan anlamlı bir farkın olmadığı sonucu ortaya çıkmıştır. Tablo 2'de öğretmen adaylarının cinsiyetleri ile Fiziksel İstismar Belirtilerini Değerlendirme Formu puanları arasından istatistiksel olarak anlamlı derecede farklılığın görülmemesi, ilgili alan yazındaki araştırma sonuçları ile benzerlik göstermektedir. Ancak durum, davranışsal özellikler ve anne-baba davranışları bölümlerinde öğretmen adaylarının sıra ortalamalarına bakıldığında; kız öğretmen adaylarının puanlarının erkek öğretmen adaylarının puanlarından daha yüksek olduğu dikkati çekmektedir. Toplumsal cinsiyet eşitsizliği nedeniyle kadınların her türlü istismar ve tacize maruz kalmaları veya kalma olasılığının kadınlar tarafından biliniyor olması çocuklara yönelik istismar konularında erkeklere göre daha duyarlı olmalarını açıklayabilir.

Öğretmen adaylarının alanlarına göre Fiziksel İstismar Belirtilerini Değerlendirme Formu'nun durum, davranışsal özellikler ve anne baba davranışları bölüm puanları arasında istatistiksel olarak anlamlı derecede farklılığın olmadığı tespit edilmiştir. Öğretmenlik alanına göre anlamlı farklılık görülmemekle birlikte, durum, davranışsal özellikler ve anne baba davranışları bölümlerinde okul öncesi öğretmenliği alanında öğrenim gören öğretmen adaylarının sıra ortalamalarının diğer alanlarda öğrenim gören öğretmen adaylarından daha yüksek olduğu görülmektedir (Tablo 3). Pala (2011) tarafından yapılan çalışmada da öğretmen adaylarının öğrenim gördükleri alanlar ile çocuk ihmal ve istismarı konusundaki bilgi ve farkındalık düzeyleri arasında istatistiksel açıdan anlamlı bir farkın olmaması araştırmadan elde edilen sonuçları 
destekler niteliktedir. Eğitim Fakülteleri'nde müfredat programları incelendiğinde, sadece Sosyal Bilgiler Öğretmenliği lisans programında "İnsan Hakları ve Demokrasi" dersinin içeriğinde çocuk hakları ve çocuk hakları ile ilgili ulusal ve uluslararası düzenlemelerin yer aldığı görülmektedir. Ayrıca Pala'nın (2011) çalışmasında öğretmen adaylarının \%91.2'sinin daha önce çocuk ihmal ve istismarı ile ilgili ders almadıkları tespit edilmiştir. Lisans programları doğrultusunda öğretmen adayları; çocuk ihmal ve istismarı ile ilgili bilgileri daha çok konferans, seminer gibi eğitici faaliyetlerden veya medyadan edinmiş olabilirler. Araştırmada öğretmen adaylarının öğrenim gördükleri Afyon Kocatepe Üniversitesi Eğitim Fakültesi Okul Öncesi Öğretmenliği Lisans Programı'nda "Çocuk İhmal ve İstismarı" seçmeli ders olarak müfredatta yer almaktadır. Seçmeli dersin içeriğinde; Türkiye'de ve dünyada çocuk ihmal ve istismarı, ihmal ve istismar türleri, belirtileri, tanı ve değerlendirme yöntemleri, çocukları ihmal ve istismardan korumak için ailelere, öğretmenlere ve topluma düşen görevler gibi konular yer almaktadır. Buna bağlı olarak okul öncesi öğretmenliği alanında öğrenim gören öğretmen adaylarının sıra ortalamalarının, diğer alanlarda öğrenim gören öğretmen adaylarından daha yüksek olduğu düşünülebilir.

Öğretmen adaylarının alanlarına göre Fiziksel İstismar Belirtilerini Değerlendirme Formu'nun durum, davranışsal özellikler ve anne baba davranışları bölüm puanları arasında istatistiksel olarak anlamlı derecede farklılığın olmadığı belirlenmekle birlikte öğretmen adaylarının durum, davranışsal özellikler ve anne baba davranışları sıra ortalamalarının 4. sınıf öğretmen adaylarında 1. sınıf öğretmen adaylarına göre daha yüksek olduğu da tespit edilmiştir (Tablo 4). Araştırmada 4.sınıf öğretmen adaylarının sıra ortalamalarının 1.sınıf öğretmen adaylarına göre daha yüksek olması, müfredat programları doğrultusunda almış oldukları derslerden ve yükseköğrenimleri sürecinde sosyal sorumluluk ve eğitimsel faaliyetlere daha fazla katılmalarından kaynaklanmış olabilir.

Ayrıca araştırmada sonucunda öğretmen adaylarının çocuk ihmal ve istismarına yönelik eğitim alma durumlarına göre Fiziksel İstismar Belirtilerini Değerlendirme Formu'nun durum ve davranışsal özellikler puan değerleri açısından istatistiksel olarak anlamlı derecede farklılık olduğu $(\mathrm{p}<.05)$, anne baba davranışları puan değerleri açısından ise istatistiksel olarak anlamlı derecede farklılık olmadığı belirlenmiştir. Sıra ortalamaları dikkate alındığında çocuk ihmal ve istismarına yönelik eğitim alan öğretmen adaylarının eğitim almayanlara göre fiziksel istismarın belirtilerini değerlendirmede daha yeterli olduğu ortaya çıkmıştır. Uysal ve Özsoy'un (2003) ve Tugay'ın (2008) öğretmenlerle yaptıkları çalışmalarında, çocuk ihmal ve istismarına yönelik eğitim alma durumunun çocuk ihmal ve istismarını belirleme olasılığında pozitif yönde bir etkiye sahip olduğu sonucu ortaya çıkmıştır. Walsh ve diğerleri (2005) çalışmalarında çocuk ihmal ve istismarı ile çocuk korumasına yönelik eğitim alma durumunun, çocuk ihmal ve istismarını belirlemede etkili olan öğretmen özelliklerinin içinde yer aldığını tespit etmişlerdir. Benzer şekilde Kenny (2004), Webster, O’Toole, O’Toole ve Lucal (2005) ile Goebbels, Nicholson, Walsh ve De Vries (2008) çalışmalarında çocuk istismarına ilişkin eğitim alan öğretmenlerin eğitim almayan 
öğretmenlere göre çocuk istismarına ilişkin daha fazla bildirim yaptıklarını belirtmişlerdir. Amerika'da yapılan bir çalışmada da genelde öğretmenlerin büyük çoğunluğunun, daha önce çocuk ihmal ve istismarına ilişkin hiç bildirim yapmadığ tespit edilmiştir. Öğretmenlerin bildirim yapmama nedenleri incelendiğinde, öğretmenlerin çocuk istismarının belirtileri konusunda eğitimleri olmasına rağmen çocuk istismarının bildirim süreci ile ilgili eğitim eksikliğinden dolayı bildirim yapamadıkları görülmüştür (Kenny, 2001). Yukarıda sözü edilen çalışmalardan elde edilen sonuçlar, çocuk ihmal ve istismarı konusunda eğitim almanın etkili olduğu sonucunu destekler niteliktedir.

\section{Öneriler}

Araştırmadan elde edilen sonuçlar doğrultusunda, günümüzde önemli bir toplumsal sorun olan çocuk ihmal ve istismarının önlenebilmesinde; çocukların aile üyelerinden sonra en fazla zaman geçirdikleri bireyler olan öğretmenler hem hizmet öncesi hem de hizmet içi eğitimlerle çocuk ihmal ve istismarının tanımlanması ve bildirilmesi konularında eğitilebilir ve bu konuda disiplinler arası işbirliği geliştirilebilir.

Çocuk ihmal ve İstismarını önlemek gerçekten güç bir konudur. Çocuk ihmal ve İstismarını önleme çalışmaları bireysel, toplumsal ve evrensel koruma yöntemleri çerçevesinde yürütülmelidir. Bu konuda en önemli sorunlardan birisi de ilgili kurum ve kişiler arasında yeterli ve etkili bir koordinasyon sağlanamamasıdır. Bu nedenle Türkiye'de çocuk ihmal ve istismarı konusunda ulusal bir organizasyon planının hazırlanması, bu organizasyon içerisinde Milli Eğitim Bakanlığı, Sağlık Bakanlığı, Adalet Bakanlığı, Aile ve Sosyal Politikalar Bakanlığı, İçişleri Bakanlığı, Çalışma Bakanlığı, Türk Tabipler Birliği, Barolar Birliği, gönüllü kişiler ve kuruluşların daha iyi bir koordinasyon içinde çalışmaları sağlanabilir.

İstismar tek bir meslek grubunun bu alanda yetkinleşmesi ile çözümlenebilecek bir sorun değildir. Bu nedenle bütün disiplinler, devletin de içinde bulunacağı bir plan çerçevesinde yetkinleşip konuyu bir ucundan tutmak ve birbirleriyle sıkı iletişimde bulunmak zorundadır. $\mathrm{Bu}$ iletişim ağında doktorlar, psikiyatristler, psikologlar, öğretmenler, sosyal hizmet uzmanları ve hukukçular arasındaki koordinasyon güçlendirilebilir. 


\section{Kaynakça}

Atamer, A. (2005). Çocuk istismarı tarama anketi: Geliştirme, geçerlilik ve güvenirlilik çalışması. Yayınlanmamış Doktora Tezi, İstanbul Üniversitesi Adli Tıp Enstitüsü, İstanbul.

Baginsky, M. (2003). Newly qualified teachers and child protection: A survey of their views, training and experiences. Child Abuse Review, 12, 119-127. doi:10.1002/car.783.

Bahar, G., Savaş, H.A. \& Bahar, A. (2009). Çocuk istismarı ve ihmali: Bir gözden geçirme. Fırat Sağlık Hizmetleri Dergisi, 4(12), 51-65.

Büyüköztürk, Ş., Kılıç-Çakmak, E., Akgün, Ö.E., Karadeniz, Ş. \& Demirel, F. (2011). Bilimsel araştırma yöntemleri. Ankara: Pegem Akademi Yayınları.

Croosson-Tower, C. (2003). The role of educators in preventing and responding to child abuse and neglect. Child Abuse and Neglect User Manual Series. U.S. Department of Health and Human Services. Retrieved from http://www.childwelfare.gov/pubs/usermanuals/educator/educator.pdf. Erişi Tarihi: 26 Mart 2012.

Çelik, G., Yolga-Tahiroğlu, A., Avcı, A., Meral, D. \& Çekin, N. (2007). Ístismar olgularında asılsız bildiri: Bir olgu sunumu. 17. Ulusal Çocuk ve Ergen Ruh Sağlığı ve Hastalıkları Kongresi (19-22 Nisan) Özet Kitabı, İzmir, s.163.

Erol, D. (2007). Okul öncesi ĕgitim kurumlarında görev yapan öğretmenlerin çocuklardaki fiziksel istismar belirtilerine ilişkin farkındalık (Eskişehir il örneği). Yayınlanmamış Yüksek Lisans Tezi. Anadolu Üniversitesi Eğitim Bilimleri Enstitüsü, Eskişehir.

Goebbels, A.F.G., Nicholson, J.M., Walsh, K. \& De Vries, H. (2008). Teachers' reporting of suspected child abuse and neglect: Behavior and determinants. Health Education Research, 23(6), 941-951. doi:10.1093/her/cyn030

Goldman, J.D.G. (2005). Student teachers' learning about child sexual abuse strategies for primary school: An exploratory study of surface and deep learning. Sex Education: Sexuality, Society and Learning, 5(1), 79-92.

Gündüz, B. \& Gökçakan, Z. (2004). Fiziksel istismar açısından üniversite öğrencilerinin problem çözme becerilerinin incelenmesi. Muğla Üniversitesi Sosyal Bilimler Enstitüsü Dergisi, 13, 29-40.

Hilal, A. (2005). Çocukta fiziksel istismar. Arşiv Kaynak Tarama Dergisi, 14(3), 403409.

Kenny, M.C. (2001). Child abuse reporting: Teachers' perceived deterrents. Child Abuse \& Neglect, 25(1), 81-92. Retrieved from http://www.ncbi.nlm.nih.gov/pubmed/11214815 Erişi Tarihi: 12 Şubat 2012.

Kenny, M.C. (2004). Teachers' attitudes toward and knowledge of child maltreatment. Child Abuse \& Neglect, 28(12), 1311-1319. doi:10.1016/j.chiabu.2004.06.010 
Lau, A.S., Huang, M.M., Garland, A.F., McCabe, K.M., Yeh, M. \& Hough, R.L. (2006). Racial variation in self-labeled child abuse and associated internalizing symptoms among adolescents who are high risk. Child Maltreatment, 11(2), 168181.

O’Toole, R., Webster, S.W., O’Toole, A.W. \& Lucal, B. (1999). Teachers' recognition and reporting of child abuse: A factorial survey. Child Abuse \& Neglect, 23(11), 1083-1101. Retrieved from http://www.ncbi.nlm.nih.gov/pubmed/10604064 Erişi Tarihi: 16 Şubat 2012.

Pala, B. (2011). Geleceğin öğretmenlerinin çocuk istismart ve ihmali konusunda bilgi ve farkındalık düzeyleri. Yayınlanmamış Tıpta Uzmanlık Tezi. Tıp Fakültesi Osmangazi Üniversitesi, Eskişehir.

Polat, O. (2007). Tüm boyutlarıyla çocuk istismarı 1: Tanımlar. Ankara: Seçkin Yayıncilik.

Reiniger, A., Robison, E. \& McHugh, M. (1995). Mandated training of professionals: A means for improving reporting of suspected child abuse. Child Abuse \& Neglect, 19(1), 63-69. Retrieved from http://www.ncbi.nlm.nih.gov/pubmed/7895145 Erişi Tarihi: 10 Mart 2012.

Stein, T.J. (1984). The child abuse prevention and treatment act. Social Service Review, 58(2), 302-314.

T.C. Resmi Gazete (2005). Çocuk Koruma Kanunu. Sayı: 25876, Başbakanlık Basimevi, Ankara. Retrieved from http://www.mevzuat.adalet.gov.tr/html/1527.html. Erişi Tarihi: 29 Mart 2012.

Tıraşçı, Y. \& Gören, S. (2007). Çocuk istismarı ve ihmali. Dicle Tip Dergisi, 34(1), 7074.

Tugay, D. (2008). Öğretmenlerin çocuk istismarı ve ihmaline yönelik farkındalık düzeyleri. Yayınlanmamış Yüksek Lisans Tezi. Marmara Üniversitesi Sağlık Bilimleri Enstitüsü, İstanbul.

U.S. Department of Health and Human Services (2011). Child maltreatment. Retrieved from htpp://www.childwelfare.gov/pubs/factsheets.pdf. Erişi Tarihi: 23 Mart 2012.

Uysal, A. \& Özsoy, S.A. (2003). Öğretmenlerin çocuk istismarı ve ihmalini içeren küçük öyküler üzerine görüş ve tutumları. Çocuk Forumu Dergisi, 6(1), 34-40.

Walsh, K., Bridgstock, R., Farrell, A. \& Schweitzer, R. (2005). Critical factors in teachers' detecting and reporting child abuse and neglect: Implications for practice. A project funded by the Abused Child Trust Final Report. Retrieved from http://eprints.qut.edu.au/777/1/ACT_Complete_Report.pdf. Erişi Tarihi: 26 Mart 2012.

Webb, R. \& Vulliamy, G. (2001). The primary teacher's role in child protection. British Educational Research Journal, 27(1), 60-77. doi:10.1080/01411920020025256. 
Webster, S.W., O’Toole, R., O’Toole, A.W. \& Lucal, B. (2005). Overreporting and underreporting of child abuse: Teachers' use of professional discretion. Child Abuse \& Neglect, 29(11), 1281-1296. doi:10.1016/j.chiabu.2004.02.007

Wood, J.N. \& Ludwig, S. (2010). Child abuse. (Eds. Fleisher, G.R. \& Ludwig, S.). Textbook of Pediatric Emergency Medicine. $6^{\text {th }}$ Edition. p.1656-1700. Philadelphia: Wolters Klewer Lippincont Williams \& Wilkins.

Yolcu, H. (2009). İstismara uğramış çocuğun eğitim ortamında yaklaşım: Rehber öğretmenin rolü. Ĕ̆itim Bilim Toplum Dergisi, 7(25), 62-92.

Yolga-Tahiroğlu, A., Avcı, A. \& Çekin, N. (2008). Çocuk istismarı, ruh sağlığı ve adli bildirim zorunluluğu. Anadolu Psikiyatri Dergisi, 9, 1-7. 